REVIEW

\title{
The Generation of Nitric Oxide and Its Roles in Neurotransmission and Neurotoxicity
}

\author{
Seikwan Oh \\ Department of Pharmacology and Toxicology, School of Medicine, University of Mississippi Medical Center,
MS, USA
}

(Received for Publication on March 8, 1995)

\begin{abstract}
The N-methyl-D-aspartate (NMDA) receptor plays a key role in synaptic plasticity and is thought to underlie memory, learning and development of the nervous system. The NMDA receptor is a ligand-gated ion channel complex that contains distinct recognition sites for endogenous and exogenous ligands, including glutamate, glycine, $\mathrm{Mg}^{2+}, \mathrm{Zn}^{2+}$, and noncompetitive blockers such as MK-801. In the central nervous system, nitric oxide (NO) is produced in some neurons following activation of excitatory amino acids receptors, particularly those of the NMDA receptor. Nitric oxide is synthesized from a L-arginine by the cytoplasmic enzyme nitric oxide synthase (NOS) which is a calcium dependent enzyme, and this pathway is inhibited by the analogues of $L$-arginine such as $\mathbf{N}^{\mathbf{G}}$-monomethyl-L-arginine (L-NMMA) and is augmented by NMDA receptor activation. Activation of the NMDA receptor results in the elevation of intracellular calcium $\left(\left[\mathrm{Ca}^{2+}\right]_{\mathrm{i}}\right)$ which in turn activates NOS via the calcium-calmodulin complex. Nitric oxide is not a classical neurotransmitter in the central nervous system since it is not released by exocytosis and does not interact with a receptor protein but rather diffuses rapidly across the membrane and binds with the iron in heme-containing proteins. Nitric oxide can serve as both an oxidizing and reducing agent. It has a strong affinity for heme proteins such as guanylyl cyclase, but there is evidence that NO may have a regulatory role by oxidizing sulfhydryl groups of non-heme proteins such as those on the NMDA receptor. The half-life of NO is 3-7 seconds, but because of its rapid rate of diffusion it can be expected to influence a sphere of cells in a radius of about $100 \mu \mathrm{m}$ from the site of its generation. One mechanism by which NO is thought to modulate long-term potentiation (LTP) and long-term depression (LTD) by the activation of guanylyl cyclase and the subsequent elevation of cGMP. In fact, elevation of cGMP induced by NMDA is enhanced by $L$-arginine and inhibited by L-NMMA. It is presumed that NO augments glutamate release, but whether this involves a linkage with cGMP is not known. Centrally, activation of the NMDA receptor is strongly linked with the rapid generation of NO in neurons, but other agonists such as kainate and acetylcholine have been shown to generate NO under selective conditions and regions of the brain. However, there are several lines of evidence suggesting that NO is a neurotoxicant. Stimulation of NMDA receptor results in the release of superoxide anion as well as NO. At least part of NO-induced toxicity results from its reaction with superoxide anion which results in the formation of a strong oxidant, peroxinitrite. (Keio J Med 44 (2): 53-61, June 1995)
\end{abstract}

Key words: glutamate receptors, nitric oxide, CGMP, LTP/LTD

\section{Characteristics of Excitatory Amino Acid Receptors}

Excitatory amino acids (EAAs) such as glutamate and aspartate are the most abundant neurotransmitters in the central nervous system (CNS). Glutamate is the major rapidly acting excitatory neurotransmitter in the mam- malian CNS and is in high concentration (approximately $100 \mathrm{mM}$ ) in glutamatergic synaptic vesicles. ${ }^{1}$ In addition, glutamate has a major metabolic role and is present at concentrations of $10 \mathrm{mM}$ in the cytoplasm of neurons. ${ }^{1}$ One metabolic pathway for glutamate involves its decarboxylation to $\gamma$-aminobutyric acid. In another reaction

Reprint requests to: Dr Seikwan Oh, Department of Pharmacology and Toxicology, School of Medicine, University of Mississippi Medical Center, 2500 North State Street, Jackson, MS 39216-4505, USA 
it may undergo transamination with oxaloacetate to form $\alpha$-ketoglutarate and aspartate. A further aspect of the metabolism of glutamate is its conversion into glutamine by the enzyme glutamine synthetase. ${ }^{2}$ The glutamate levels found in rat plasma, cerebrospinal fluid and hippocampal extracellular fluid are 160,11 and $3 \mu \mathrm{M}$ respectively. ${ }^{3}$ The glutamate is removed by reuptake into both neurons and glia by high-affinity transport system which is an uptake carrier that cotransports two sodium ions into the cell with each glutamate anion, while counter-transporting one potassium ion and one hydroxide ion out of the cell. ${ }^{4,5}$

Receptors for glutamate have been divided into two distinct groups: Ionotropic glutamate receptors (iGluRs) and metabotropic glutamate receptors. Three classes of iGluRs have been characterized. They are permeable to cations and further classified according to compounds which preferentially activate the receptor: N-methyl-Daspartate (NMDA), kainate and a-amino-3-hydroxyl-5methylisoxazole-4-propionate (AMPA). Antagonists have been found which are selective for each of these ionotropic receptors: D-2-amino-5-phosphonovalerate and 3-(2-carboxypiperazine-4-yl)-propyl-1-phosphonoate for the NMDA receptor; 6-cyano-7-nitroquinoxaline-2, 3-dione and 6,7-nitroquinoxaline-2,3-dione for the kainate receptor; and 2-amino-3-[3-(carboxymethoxy)5-methy-losoxazole-4-yl]-propionate for the AMPA receptor. A second main class of glutamate receptors is a mGluR which is activated by both trans 1 -aminocyclopentane-1,3-dicarboxylate and quisqualate. This receptor can be blocked by the selective antagonist, L-2-amino-3phosphonopropionate. ${ }^{6.7}$

NMDA receptor currents behave like classical voltagedependent channels, which increase their activity with depolarization. Because NMDA receptor activation requires two types of input (binding of agonist such as glutamate, and depolarization to reduce $\mathrm{Mg}^{2+}$ block), the synaptic activation of NMDA receptors shows associative properties. In vivo, glycine is present in the extracellular fluids at sufficient concentration to ensure a high degree of occupancy at its binding site. Thus, synaptic activation of NMDA receptors can be triggered solely by the release of glutamate.

The NMDA receptor has a conductance of approximately $50 \mathrm{pS}$, a mean open time of $5 \mathrm{~ms},{ }^{8.9}$ and a $10 \times$ higher permeability to calcium over sodium ions. ${ }^{10}$ This is in contrast with the kainate receptor which is selectively permeable to sodium over calcium. ${ }^{11,12}$

The EAAs such as NMDA, glutamate, and kainate have been shown to produce neurodegeneration both in vivo ${ }^{13,14}$ and in vitro. ${ }^{15,16}$ There are two phases of neuronal injury in vitro: An immediate phase, which is often reversible and occurs within a few minutes of glutamate application, is characterized by cell swelling and is dependent on sodium and chloride influx. ${ }^{17.18}$
A delayed phase occurs 24 hours later and is dependent on an increase in intracellular calcium concentration $\left(\left[\mathrm{Ca}^{2+}\right]_{i}\right) \cdot{ }^{15,19}$ Using neuronal culture, it has been shown that excitotoxins require the presence of chloride but not calcium for rapid toxicity to occur and that calcium is involved in the delayed toxicity. ${ }^{20,21}$ In fact, in zerocalcium buffer a rapid NMDA receptor-mediated toxicity secondary to both the influx of chloride and water in conjunction with the efflux of glutamate occurs in the absence of exogenously added toxicant. ${ }^{22}$ Measurements of $\left[\mathrm{Ca}^{2+}\right]_{i}$ with the fluorescence dye fura- 2 show that a neurotoxic dose of glutamate $(50 \mu \mathrm{M})$ results in a 10 -fold elevation of $\left[\mathrm{Ca}^{2+}\right]_{i} \cdot{ }^{23}$ Some have shown $\left[\mathrm{Ca}^{2+}\right]_{i}$ remains elevated for longer than $1 \mathrm{hr}$ after glutamate withdrawal, ${ }^{15}$ whereas others have shown that $\left[\mathrm{Ca}^{2+}\right]_{i}$ return to normal even though there is an ensuing cell death. ${ }^{24}$ Thus, the role of calcium in cell death is not clear.

The calcium entry that results from the opening of the NMDA channel can induce the membrane translocation and activation of protein kinase $\mathrm{C}$ (PKC) ${ }^{25}$ which, in turn, mediates the phosphorylation of specific membrane proteins. Sustained increase of neuronal calcium influx which is insensitive to NMDA antagonists and voltage sensitive calcium channel blockers may be triggered by the activation of PKC. ${ }^{15}$ A prolonged activation of $\mathrm{PKC}$ has been detected in vivo after brain ischemia. $^{26}$ Prevention of glutamate- and kainateinduced PKC translocation by gangliosides ${ }^{27,28}$ or downregulation of $\mathrm{PKC}$ by phorbol esters ${ }^{29}$ protects neurons from glutamate-induced delayed toxicity. Thus, it is possible that glutamate neurotoxicity may be mediated by a sustained PKC translocation, which results in the unbalancing of $\left[\mathrm{Ca}^{2+}\right]_{i}$ homeostasis.

Recently the function of the NMDA receptor and possibly the toxicity that results from activation of the receptor has been linked to nitric oxide (NO) production. ${ }^{30,31}$ Nitric oxide is now thought to be a neurotransmitter in the CNS that is closely linked with the iGluR activation (Fig 1). In the next section, the characteristics of nitric oxide synthase and the roles of NO in the central nervous system will be discussed.

\section{The Localization of Nitric Oxide Synthase}

Immunohistochemical staining with antiserum against NOS and in situ hybridization with NOS MRNA revealed that the enzyme was located entirely in neurons and vasculature endothelium of the brain with no staining or hybridization occurring in glia. ${ }^{34-36}$ In these studies the highest amounts of NOS occurred in the granule cells layer of the cerebellum and the olfactory bulb, while only about $2 \%$ of the neurons in the cerebral cortex, striatum and hippocampus stained for NOS and these were mostly aspiny neurons. ${ }^{37}$ Subsequent studies, however, with polyclonal antibodies against cerebellar NOS 


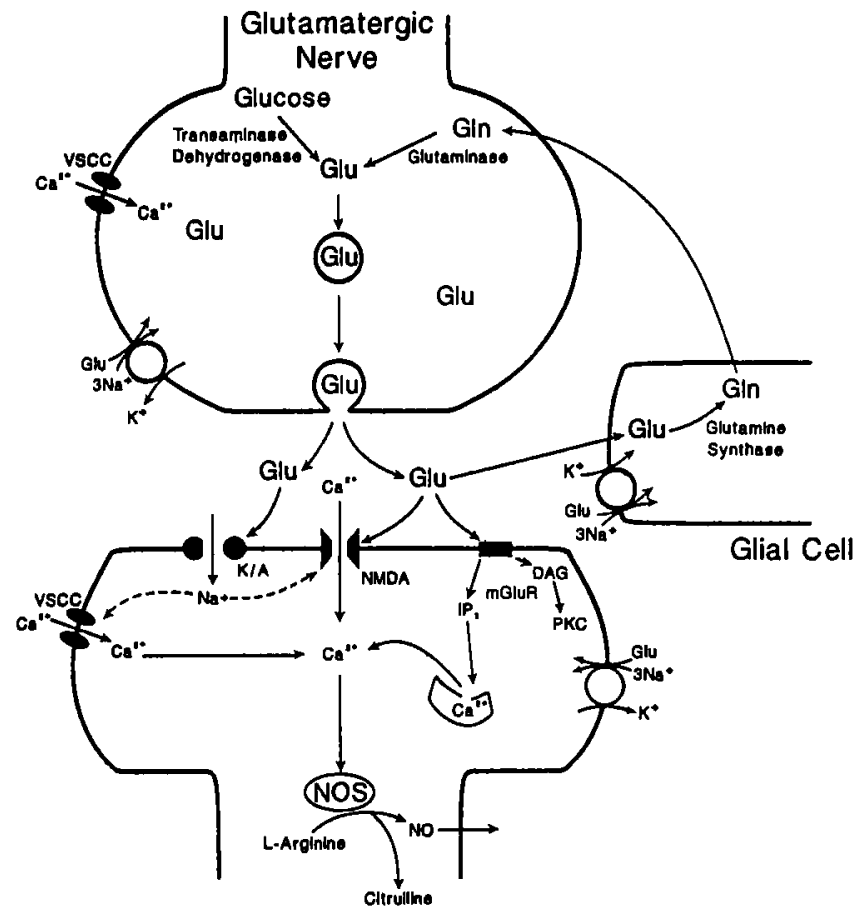

Fig 1 Schematic diagram of a glutamatergic synapse, showing glutamate synthesis and release from the presynaptic neuron, action of glutamate on postsynaptic ion channels, and removal of glutamate from the extracellular space by uptake. Postsynaptically glutamate can activate excitatory amino acid (EAA) receptors which allow elevation of intracellular calcium levels. Elevated intracellular calcium via NMDA receptor activation can activate NOS results in generation of NO. Glu; glutamate, Gln; glutamine, NMDA, NMDA receptor; K/A, KA/AMPA receptor, mGluR; metabotropic glutamate receptor, VSCC; voltage sensitive calcium channel, NOS; nitric oxide synthase

revealed that the NOS was not exclusively found in neurons, but rather glia stained as well as non-neural cells in the pancreas, lung, kidney, uterus and stomach. ${ }^{38}$ However, selective staining was still found in neuronal tissues, and it was often found that cells staining for NOS had adjacent areas which stained heavily for guanylyl cyclase.

While no NOS was detected in glia in the above studies, it now appears that there are a family of enzymes and it is possible that there are other NO generating proteins that were not detected by the above methods. Under various conditions astrocytes show both constitutive and inducible NOS activity. ${ }^{39}$ A polyclonal antiserum against NOS different from the above studies showed staining that included Bergmann glia and astrocytes although at a lower level. ${ }^{38}$ Indirect evidence comes from the finding that glutamate, norepinephrine and calcium ionophores cause an elevation of cGMPin cerebral astrocytes that is reversed by NOS inhibitors. ${ }^{40}$ Furthermore, NOS activity can be induced in microglia, the CNS analog to macrophages, by lipopolysaccharide ${ }^{41}$ and in cortical astrocytes in culture. ${ }^{42,43}$ Primary cultures of forebrain astrocytes release $\mathrm{NO}$ as measured with chemiluminescence after stimulation with bradykinin, quisqualate, norepinephrine or the calcium ionophore A23187, which is blocked by hemoglobin or arginine analogs. ${ }^{44}$ The most potent activator of rapid NO synthesis in astrocytes is norepinephrine and quisqualate ${ }^{40,44}$ which contrast with NMDA for neurons.

When NO synthase was measured in primary cultures of astrocytes from the cerebellum, no activity was found as measured by the conversion of $\left[{ }^{3} \mathrm{H}\right]$ arginine to $\left[{ }^{3} \mathrm{H}\right]$ citrulline. ${ }^{45}$ Activity was demonstrated in cerebellar granule cells, however, when astrocyte cultures were placed upside down over granule cells so that they were in close proximity, NO generated by the neurons stimulated elevations in cGMP induced by NMDA which was blocked by NOS inhibitors. NOS is not found in the Purkinje cells of the cerebellum or many pyramidal cells of the hippocampus, although there is a subset of pyramidal cells which stain for $\operatorname{NOS}^{38}$ : The presence of NOS in these cells is a necessity if NO is to be linked with long-term potentiation (LTP) and long-term depression (LTD) that occurs in these cells. However, it is possible that other cells in close proximity supply the necessary NO. Another possibility is that there are isozymes of NOS that are not detected by the immunohistochemical staining. Consistent with this possibility are large concentrations of a particulate NOS that has recently been found in the cerebellum. ${ }^{46}$ Nitric oxide synthase is colocalized with NADPH diaphorase in all regions of the brain and in every tissue in the body with the exception of the adrenal cortex which stains for NADPH diaphorase but not for NOS. In some areas of the striatum, NOS is colocalized with somatostatin and neuropeptide $\mathrm{Y} .{ }^{47}$

\section{Inhibitors and Triggers of Nitric Oxide Synthesis}

\section{Nitric oxide synthase inhibitors}

Nitric oxide synthase is inhibited by the structural analogues of $\mathrm{L}$-arginine such as $\mathrm{N}^{\mathrm{G}}$-monomethyl- $\mathrm{L}$ arginine (L-NMMA), $\mathrm{N}^{\mathrm{G}}$-nitro-L-arginine methyl ester (L-NAME) and $\mathrm{N}^{\mathrm{G}}$-iminomethyl-L-ornithine (L-NIO), ${ }^{48,49}$ Interestingly, 7-nitroindazole which is not a guanidino-substituted L-arginine analogue also inhibits NOS. ${ }^{50}$ Inducible NOS is much less sensitive to L-NAME than is the constitutive enzyme. ${ }^{51}$ As with the case of the NO generating agents, the arginine analogs are not entirely selective for inhibiting NOS. L-NMMA and L-NIO inhibit the transport of L-arginine whereas L-NAME does not. ${ }^{52}$ On the other hand, L-NAME and other alkyl esters of arginine have muscarinic receptor antagonist properties. ${ }^{53}$ The lack of specificity of the arginine analogs is often ignored in many experimental protocols. 
There are interesting agents that block NO synthesis by interfering with various cofactor binding sites. Carbon monoxide binds to the heme site on NOS to partially inhibit enzyme function. Interestingly, NO binds to the same site and negatively inhibits its own formation ${ }^{54}$ and affects expression of NOS mRNA. ${ }^{55}$ Diphenyleneiodonium and chemically related compounds are aromatic iodoniums that block NOS by covalently modifying the enzyme. ${ }^{56}$ Miconazole inhibit both cytochrome P-450 reductase and NOS probably by interfering with the $\mathrm{CA}^{2+}$-calmodulin binding site ${ }^{57}$ as do fluperazine and calcineurin. ${ }^{58}$ With the exception of diphenyleneiodonium which may prove to be a potent and selective inhibitor, it is clear that none of these agents are selective for NOS. Recently, there is an interesting report suggests that glucocorticoids have the downregulating role on NO production via the inhibition of PKC activity particularly under the conditions of stimulated production of NO, such as inflammatory and demyelinating CNS disorders. ${ }^{59}$

\section{Nitric oxide generating agents}

For many years sydnonimines, sodium nitroprusside, various nitrates such as nitroglycerin (glyceryl trinitrate) and nitrite such as amyl nitrite have been used as vasodilators and anti-angional agents. The muscle relaxing properties of these agents were thought by some to depend on the formation of nitric oxide. ${ }^{60} \mathrm{~A}$ decade later, NO was shown to be synonymous with endotheliumderived relaxing factor. ${ }^{61,62}$ It is possible that at least some of the effects of the NO generating agents are mediated by S-nitrosocysteine. ${ }^{63}$ A sydnonimine, 3-morpholinosydnonimine (SIN-1), produces both NO and superoxide anion in its spontaneous degradation which combines to form peroxynitrite. ${ }^{64}$ Some nitric oxide generating compound such as molsidomin require initial degradation by hepatic enzymes to SIN-1.

Sodium nitroprusside and S-nitroso-N-acetylpenicillamine generate NO spontaneously while neither nitroglycerin nor amyl nitrite is spontaneously decomposed in aqueous solutions to NO. Rather, in the absence of light nitroglycerin interacts with thiol groups to form an intermediate nitrosonium ion $\left(\mathrm{S}-\mathrm{NO}^{+}\right)$. This is the likely reason that nitroglycerin is neuroprotective while SIN-1 is neurotoxic: ${ }^{64}$ The production of an $\mathrm{NO}^{+}$ equivalent (RS-NO) by nitroglycerin provides protection by serving as oxidizing agents while the generation of peroxynitrite by SIN-1 has toxic effect. In fact, when neurons are co-incubated with nitroglycerin plus a reducing agent such as cysteine, nitroglycerin which spontaneously release $\mathrm{NO}^{+}$becomes neurotoxic as is the case with SIN-1 because nitrosonium could be reduced by reducing agent into nitric oxide then reacts with superoxide to produce peroxynitrite.

\section{Triggers of nitric oxide synthesis}

Triggers for NO generation in CNS were first shown to be glutamate which resulted in the stimulation of cerebellar granule cells to produce NO. ${ }^{65-68}$ The concentration of NO which has a short half life can be measured indirectly by cGMP elevation or nitrite accumulation. The elevation of cGMP was blocked by NMDA antagonists, and in fact, NMDA receptor activation has been the glutamate receptor best associated with NO generation. In immature cerebellar slices, only the activation of the NMDA receptor is associated with the synthesis of NO. ${ }^{69}$ However, in mature cerebellar slices, both quisqualate and AMPA receptor activation result in the formation of NO, again as measured by cGMP elevations and similarly inhibited by hemoglobin and arginine analogues. ${ }^{66-68,70}$ The release of nitric oxide in response to NMDA is $\mathrm{Ca}^{2+}$-dependent. ${ }^{65}$ Since the action of guanylyl cyclase by sodium nitroprusside is $\mathrm{Ca}^{2+}$-independent, it seems likely that $\mathrm{Ca}^{2+}$ is necessary for NO synthesis as opposed to the synthesis of cGMP as was previously thought. When the glutamate-induced cGMP elevation was discovered, this effect was presumed a nonspecific consequence of depolarization-induced influx of $\mathrm{Ca}^{2+}$ into the stimulated neuron, and a subsequent activation of guanylyl cyclase by this ion. Thus, the key step in the production of $\mathrm{NO}$ is probably the influx of $\mathrm{CA}^{2+71}$ and increased $\left[\mathrm{Ca}^{2+}\right]_{i}$ levels that are maintained.

In striatal neurons in tissue culture, the non-NMDA agonist, domoate, kainate, AMPA and quisqualate can stimulate the production of NO. ${ }^{72}$ If neurons are treated with concanavalin $\mathrm{A}$, the production of $\mathrm{NO}$ (as measured by elevations of cGMP) is markedly elevated and is partially blocked by MK- 801 suggesting that these non-NMDA agonist were activating a glutamate receptor subtype composed of both kainate and NMDA receptor subunits. ${ }^{72}$ In primary cultures of cerebellar granule cells, activation of both the NMDA and kainate receptors are associated with the synthesis of NO as measured by the production of $\left[{ }^{3} \mathrm{H}\right]$ citrulline from $\left[{ }^{3} \mathrm{H}\right]$ arginine, however, only the production of $\left[{ }^{3} \mathrm{H}\right]$ citrulline induced by NMDA was correlated with elevations of cGMP. ${ }^{73}$ In vivo, elevations of cerebellar cGMP induced by D-serine, quisqualate, NMDA, kainate, harmaline and pentylenetetrazol are blocked by arginine analogues. ${ }^{74}$ In primary cultures of astroglial cells derived from cerebral cortex, norepinephrine and quisqualate result in elevations of NO via the $\alpha_{1}$-adrenergic and the metabotropic glutamate receptors, respectively. ${ }^{75}$

\section{The Physiologic and Pathologic Roles of Nitric Oxide}

Nitric oxide is thought to be a neurotransmitter. However NO is not a classical neurotransmitter be- 
cause it is not stored in synaptic vesicles or released by exocytosis and is not thought interact with a receptor protein. But it rather diffuses rapidly across the membrane of target neurons where it binds with the iron in heme-containing proteins. ${ }^{76}$ The effects of NO have been varied. They include altering synaptic efficiency by mediating such processes as long-term potentiation. Nitric oxide has been linked with some types of glutamateinduced neurotoxicity. It has been proposed that NO might have a role in synaptogenesis during development. ${ }^{77}$ Nitric oxide lowers $\left[\mathrm{Ca}^{2+}\right]_{i}$ in Balb/c $3 \mathrm{~T} 3$ cells, which lacks guanylyl cyclase ${ }^{78}$ so that it is clear that the mechanism is not mediated by elevations of cGMP. Nitric oxide regulates pripheral vascular blood flow and is synonymous with enothelial-derived relaxing factor. Nitric oxide production in various regions of the brain might effect local vascular responses in a similar manner as seen in the periphery such that blood flow is controlled in a need-dependent fashion. Nitric oxide synthase inhibitors block the increase in blood flow in the somatosensory cortex that occurs normally upon stimulation of peripheral nerves. ${ }^{79}$ The following discussion will examine more closely the effects of $\mathrm{NO}$ as a neurotransmitter in the CNS, particularly the role of NO in long-term potentiation/long-term depression and explore the toxic effect of NO.

\section{Long-term potentiation and long-term depression}

NO has been proposed as an intercellular transsynaptic messenger in models of synaptic plasticity such as LTP and LTD, two processes that have been linked with memory formation. ${ }^{80,81}$ Long-term potentiation occurs in the hippocampus after a neuron or group of neurons receive several simultaneous signals. Changes occur so that when the neuron is stimulated at a later time, a greater response occurs, and it is clear that the NMDA receptor with subsequent elevations of $\left[\mathrm{Ca}^{2+}\right]_{i}$ are involved. But it is unclear whether the potentiation is due to an increase in the sensitivity of the receiving neuron (postsynaptic receptor) or to an increase in the amount of neurotransmitter released by the sending neuron (presynapse). Evidence exists that NO acts as a retrograde transmitter to change the sending neuron and thus affect the amount of transmitter that is released 82-86 and NO stimulates $\mathrm{Ca}^{2+}$-independent synaptic vesicle release ${ }^{87}$ Nitric oxide synthase inhibitors block LTP in tissue slice experiments while NO generating agents such as sodium nitroprusside mimics LTP. Furthermore, the effects can be blocked by hemoglobin which is impermeable to the cell thus implicating an effect of NO that extends beyond the generating cell. NOS inhibitors show similar results with the inhibitors able to block the ability of rats to learn spatial tasks. ${ }^{88,89}$ On the other hand, there is also evidence that NO is affecting the receiving neuron as well. NOS inhibitor, L-NMMA, partially prevented the NMDA-induced elevations of glutamate release and $\left[\mathrm{Ca}^{2+}\right]_{i}$ levels. ${ }^{90,91}$ The effect of NO on glutamate release in unlikely to be secondary to cGMP as the cGMP analogue, dibutyryl cGMP (dBcGMP), does not augment basal or NMDAinduced glutamate release. However, dBcGMP augments the NMDA-induced elevations of $\left[\mathrm{Ca}^{2+}\right]_{i}$ levels. Part of the effect of cGMP might be via positive feedback

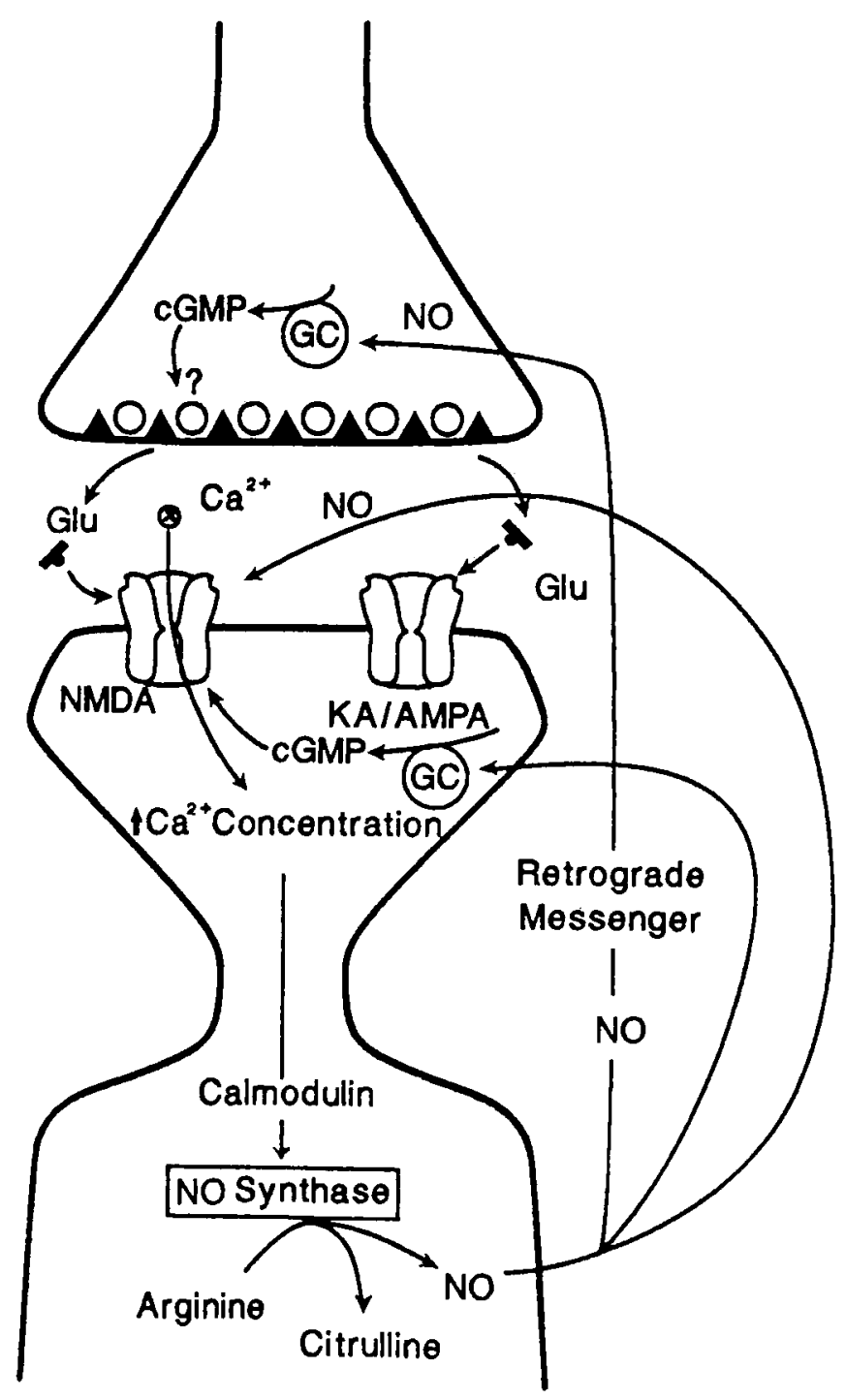

Fig 2 Proposed physiologic and pathologic roles of NO in the CNS. The activation of NMDA receptor produces NO and generated NO can act as a retrograde messenger, causing a long-lasting increase in neurotransmitter release from the presynaptic terminals by stimulating guanylyl cyclase (GC) or directly effect on synaptic vesicles. In other hand, NO may have a role in maintaining of NMDA receptor activation via cGMP elevation in postsynaptic level, perhaps due to a phosphorylation of NMDA receptor. However, high concentration of NO which is generated under pathologic conditions downregulates NMDA receptor probably by modulation of redox site on NMDA receptor. NMDA, NMDA receptor; K/A, KA/AMPA receptor. 
on the NMDA receptor (Fig 2) since dBcGMP increases $\left[{ }^{3} \mathrm{H}\right] \mathrm{MK}-801$ specific binding in cultured cerebellar granule cells (unpublished data). The problem with the retrograde messenger theory is that the NO should be made in the appropriate postsynaptic cells which are the pyramidal cells of the hippocampus. However, no NOS has been found in these cells. Furthermore, some laboratories have not found a consistent block of LTP by NOS inhibitors. ${ }^{92}$

Long-term depression is similar but opposite condition to LTP occurring in the cerebellum where long-term firing of parallel and climbing fibers suppresses Purkinje cell firing, the sole output of the cerebellum. Nitric oxide is released following the stimulation of the climbing fibers and LTD can be blocked in a similar manner as LTP by both arginine analogs and hemoglobin. ${ }^{82}$ A combination of sodium nitroprusside and 8-bromocyclic GMP (a cGMP analog) in conjunction with parallel fiber stimulation can substitute for climbing fiber stimulation in producing LTD in Purkinje cells. Thus, there is likely a role for both NO and one of its effector proteins, guanylyl cyclase in LTD. Quisqualate has also been report to induce LTD in Purkinje cells which is blocked by hemoglobin and arginine analogues. ${ }^{93}$

\section{Neurotoxicity}

There are several lines of evidence which suggest a role for NO in neurotoxicity. Nitric oxide synthase occurs in discrete neuronal populations in a distribution that is identical to that of neurons staining for NADPHdiaphorase. ${ }^{36.94 .95}$ Interestingly, it is the neurons containing NOS that are spared in the striatum in Huntington's disease ${ }^{96}$ and in other brain regions after ischemic $^{97}$ and excitotoxin (quinolinate) induced damage. ${ }^{98}$ In tissue culture, neurons containing NOS are resistant to NMDA-induced neurotoxicity and are usually more sensitive to kainate-induced toxicity. ${ }^{20,99,100}$ In cultured cortical neurons some investigators have shown that NOS inhibitors can prevent NMDA-induced toxicity ${ }^{30,31}$ while others have noted no association. ${ }^{101,102}$ Ischemic brain damage caused by ligation of cerebral arteries can be markedly reduced by various arginine analog type NOS blockers. ${ }^{103}$ At least part of NOinduced toxicity results from its reaction with superoxide anion which results in the formation of peroxynitrite. ${ }^{64}$

Nitric oxide synthase inhibitors or superoxide dismutase (SOD) either provides partial protection against cerebral ischemia in rats that have had their middle cerebral arteries occluded or markedly potentiates the toxicity depending on whether the inhibitor are given before or after the occluding insult. ${ }^{103,104}$ The pretreatment of animals with NOS inhibitors augments the injury while the post-treatment reduces the infarct size.

Some NO generating agents have been shown to be toxic to cultures of cortical neurons while others are neuroprotective. The toxicity of compounds such as SIN1 are prevented by simultaneously incubating cultures with superoxide dismutase indicating that these compounds further combined with $\mathrm{O}_{2}^{-}$to form $\mathrm{ONOO}^{-}$ (poroxynitrite) that is apparently the lethal product. ${ }^{64}$ On the other hand, $\mathrm{NO}^{+}$(nitrosonium) generating agents such as nitroglycerin which do not form peroxynitrite but serve as neuroprotective agents probably through the downregulation (oxidation) of the NMDA receptor. ${ }^{105}$

It is possible that other radicals besides $\mathrm{NO}$ contribute to some of the toxicity that results from activation of glutamate receptors. For example, several mutations in superoxide dismutase are associated with the autosomal dominant inheritance of familial amyotrophic lateral schlerosis, ${ }^{106}$ a neurodegenerative disorder that has been linked with excessive glutamate excitation. In primary cultures of cerebellar granule cells, stimulation of the NMDA receptor results in the release of superoxide radical as assessed with electron paramagnetic resonance studies. ${ }^{107}$ The superoxide radicals came from the release of arachidonic acid and could be prevented by a phospholipase $\mathrm{A}_{2}$ inhibitor. Neither stimulation with kainate or membrane depolarization with $\mathrm{KCl}$ produced similar superoxide radicals, and the production of superoxide was not dependent on the NO. Superoxide radicals were dependent on the presence of calcium in the extracellular fluid and could be blocked with MK-801. ${ }^{107}$ On the other hand, others have shown that kainate-induced toxicity in cerebellar granule cells can be prevented by inhibitors of xanthine oxidase, a cellular source of superoxide, ${ }^{108}$ however NMDA-induced neuronal death was not blocked by superoxide dismutase and xanthine oxidase-induced neuronal death was not potentiated by SIN-1. ${ }^{109}$ This indicates that peroxinitrite is not more toxic than superoxide radical in cerebellar granule cells. Nevertheless, there is a possible pathologic link of SOD with NO. Superoxide ion reacts with NO three times faster than it does with the SOD to form peroxynitrite $\left(\mathrm{ONOO}^{-}\right)$, and peroxynitrite reacts with tyrosine residues on SOD.

In tissue culture, inhibitors of NOS block neurotoxicity induced by HIV virus coat protein, gp120, indicating a role for NO in AIDS dementia. ${ }^{110}$ Toxicity induced by gp120 requires glutamate and is also blocked by NMDA receptor antagonists as well as superoxide dismutase indicating that toxicity is possibly mediated by peroxynitrite. In some cases, the toxicity of NO might be secondary to cGMP synthesis. High levels of cGMP cause destruction of photoreceptor cells in the retina $^{111}$ where NOS has now been demonstrated by immunocytochemistry. ${ }^{34}$ Sodium nitroprusside produces a concentration dependent cell death that parallels cGMP formation, and this neurotoxic effect can also be prevented by hemoglobin. ${ }^{30}$ 


\section{References}

1. Taylor CP, Geer JJ, Burke SP: Endogenous extracellular glutamate accumulation in rat neocortical cultures by reversal of the transmembrane sodium gradient. Neurosci Lett 1992, 145: $197-200$

2. Kruk ZL, Pycock CJ: Excitatory amino acids: L-glutamic acid and L-aspartic acid. In: Kruk ZL, Pycock CJ, eds, Neurotransmitters and Drugs, London, Chapman \& Hall, 1991, 159-168

3. Lerma J, Herranz AS, Herreras O, Abraira V, Martin del Rio $\mathrm{R}$ : In vivo determination of extracellular concentration of amino acids in the rat hippocampus. A method based on brain dialysis and computerized analysis. Brain Res 1986, 384: 145-155

4. Flott B, Seifert W: Characterization of glutamate uptake systems in astrocyte primary cultures from rat brain. Glia 1991, 4: 293-304

5. Bouvier M, Szatkowski M, Amato A, Attwell D: The glial cell glutamate uptake carrier countertransports $\mathrm{pH}$-changing anions. Nature 1992, 360: 471-474

6. Schoepp DD, Johnson BG: Comparison of excitatory amino acid-stimulated phosphoinositide hydrolysis and $\mathrm{N}-\left[{ }^{3} \mathrm{H}\right]$ acetylaspartyglutamate binding in rat brain: selective inhibition of phosphoinositide hydrolysis by 2-amino-3-phosphonopropionate. $\mathrm{J}$ Neurochem 1989, 53: 273-278

7. Schoepp D, Bockaert J, Sladeczek F: Pharmacological and functional characteristics of metabotropic excitatory amino acid receptors. Trends Pharmacol Sci 1990, 11: 508-515

8. Jahr CE, Stevens CF: Glutamate activates multiple single channel conductances in hippocampal neurones. Nature 1987, 325: $522-525$

9. Ascher P, Bregestovski P, Nowak L: N-methyl-D-aspartateactivated channels of mouse central neurones in magnesium-free solutions. J Physiol 1988, 399: 207-226

10. MacDermott AB, Mayer ML, Westbrook GL, Smith SJ, Barker JL: NMDA-receptor activation increases cytoplasmic calcium concentration in cultured spinal cord neurones. Nature 1986, 321: $519-522$

11. Mayer ML, Westbrook GL: Permeation and block of N-methyl$\mathrm{D}$-aspartic acid receptor channels by divalent cations in mouse cultured central neurones. J Physiol 1987, 394: 501-527

12. Mayer ML, Vyklicky L Jr, Sernagor E: A physiologist's view of the N-methyl-D-aspartate receptor: an allosteric ion channel with multiple regulatory sites. Drug Dev Res 1989, 17: $263-280$

13. Olney JW: Excitotoxic amino acids and Huntington's disease. In: Chase TN, Wexler NS, Barbeau A, eds. Huntington's Disease (Advances of Neurology), New York, Raven Press, 1979, $609-624$

14. Olney JW, Price MT, Samson L, Labruyere J: The role of specific ions in glutamate neurotoxicity. Neurosci Lett 1986, 65: 65-71

15. Manev H, Favaron M, Guidotti A, Costa E: Delayed increase of $\mathrm{Ca}^{2+}$ influx elicited by glutamate: role in neuronal death. Mol Pharmacol 1989, 36: 106-112

16. Regan RF, Choi DW: Glutamate neurotoxicity in spinal cord cell culture. Neuroscience 1991, 43: 585-591

17. Choi DW: Calcium-mediated neurotoxicity: relationship to specific channel types and role in ischemic damage. Trends Neurosci 1988, 11: 465-469

18. Koh JY, Goldberg MP, Hartley DM, Choi DW: Non-NMDA receptor-mediated neurotoxicity in cortical culture. J Neurosci 1990, 10: 693-705

19. Manev H, Favaron M, Vicini S, Guidotti A, Costa E: Glutamateinduced neuronal death in primary cultures of cerebellar granule cells: protection by synthetic derivatives of endogenous sphingo- lipids. J Pharmacol Exp Ther 1990, 252: 419-427

20. Choi DW: lonic dependence of glutamate neurotoxicity. J Neurosci 1987, 7: 369-379

21. Rothman SM, Thurston JH, Hauhart RE: Delayed neurotoxicity of excitatory amino acids in vitro. Neuroscience 1987, 22: $471-480$

22. McCaslin PP, Smith TG: Low calcium-induced release of glutamate results in autotoxicity of cerebellar granule cells. Brain Res 1990, 513: 280-285

23. Manev H, Favaron M, De Erausquin G, Guidotti A, Brooker G, Costa E: Destabilization of ionized $\mathrm{Ca}^{2+}$ homeostasis in excitatory amino acid neurotoxicity: antagonism by glycosphingolipids. Cell Biol Int Rep 1990, 14: 3-14

24. Randall RD, Thayer SA: Glutamate-induced calcium transient triggers delayed calcium overload and neurotoxicity in rat hippocampal neurons. J Neurosci 1992, 12: 1882-1895

25. Vaccarino F, Guidotti A, Costa E: Ganglioside inhibition of glutamate-mediated protein kinase $\mathrm{C}$ translocation in primary cultures of cerebellar neurons. Proc Natl Acad Sci USA 1987, 84: $8707-8711$

26. Onodera $\mathrm{H}$, Araki T, Kogure K: Protein kinase $\mathrm{C}$ activity in the rat hippocampus after forebrain ischemia: autoradiographic analysis by $\left[{ }^{3} \mathrm{H}\right]$ phorbol 12,13 -dibutyrate. Brain Res 1989,481 : 1-7

27. Favaron M, Manev $\mathbf{H}$, Alho $\mathrm{H}$, Bertolino M, Ferret B, Guidotti A, Costa E: Gangliosides prevent glutamate and kainate neurotoxicity in primary neuronal cultures of neonatal rat cerebellum and cortex. Proc Natl Acad Sci USA 1988, 85: 7351-7355

28. Favaron M, Manev H, Vicini S, Guidotti A, Costa E: Prevention of excitatory amino acid-induced neurotoxicity by natural and semisynthetic sphingoglycolipids. In: Guidotti A, ed, Neurotoxicity of Excitatory Amino Acids, New York, Raven Press, 1990, 243-258

29. Maney H, Favaron M, Bertolino M, Brooker G, Guidotti A, Costa $E$ : Importance of sustained protein kinase $C$ translocation and destabilization of $\mathrm{Ca}^{2+}$ homeostasis in glutamate-induced neuronal death. In: Guidotti A, ed, Neurotoxicity of Excitatory Amino Acids, New York, Raven Press, 1990, 63-78

30. Dawson VL, Dawson TM, London ED, Bredt DS, Snyder SH: Nitric oxide mediates glutamate neurotoxicity in primary cortical cultures. Proc Natl Acad Sci USA 1991, 88: 6368-6371

31. Izumi Y, Benz AM, Clifford DB, Zorumski CF: Nitric oxide inhibitors attenuate $\mathrm{N}$-methyl-D-aspartate excitotoxicity in rat hippocampal slices. Neurosci Lett 1992, 135: 227-230

32. Leone AM, Palmer RM, Knowles RG, Francis PL, Ashton DS, Moncada S: Constitutive and inducible nitric oxide synthases incorporate molecular oxygen into both nitric oxide and citrulline. J Biol Chem 1991, 266: 23790-23795

33. Stuehr DJ, Kwon NS, Nathan CF, Griffith OW, Feldman PL, Wiseman $\mathrm{J}: \mathrm{N}^{\prime \prime}$-hydroxy-L-arginine is an intermediate in the biosynthesis of nitric oxide from L-arginine. J Biol Chem 1991 , 266: 6259-6263

34. Bredt DS, Hwang PM, Snyder SH: Localization of nitric oxide synthase indicating a neural role for nitric oxide. Nature 1990 . 347: 768-770

35. Bredt DS, Glatt CE, Hwang PM, Fotuhi M, Dàwson TM, Snyder SH: Nitric oxide synthase protein and mRNA are discretely localized in ncuronal populations of the mammalian CNS together with NADPH diaphorase. Neuron 1991, 7: 615-624

36. Dawson TM, Bredt DS, Fotuhi M, Hwang PM, Snyder SH: Nitric oxide synthase and neuronal NADPH diaphorase are identical in brain and peripheral tissues. Proc Natl Acad Sci USA 1991, 88: 7797-7801

37. Forstermann U, Gorsky LD, Pollock JS, Schmidt HH, Heller M, Murad F: Regional distribution of EDRF/NO-synthesizing enzyme(s) in rat brain. Biochem Biophys Res Commun 1990 , 
168: $727-732$

38. Schmidt HH, Gagne GD, Nakane M, Pollock JS, Miller MF, Murad F: Mapping of neural nitric oxide synthase in the rat suggests frequent co-localization with NADPH diaphorase but not with soluble guanylyl cyclase, and novel paraneural functions for nitrinergic signal transduction. J Histochem Cytochem 1992, 40: $1439-1456$

39. Murphy S, Simmons ML, Agullo L, Garcia A, Feinstein DL, Galea E, Reis DJ, Minc-Golomb D, Schwartz JP: Synthesis of nitric oxide in CNS glial cells. Trends Neurosci 1993, 16: 323328

40. Agullo L, Garcia A: Different receptors mediate stimulation of nitric oxide-dependent cyclic GMP formation in neurons and astrocytes in culture. Biochem Biophys Res Commun 1992, 182: $1362-1368$

41. Boje KM, Arora PK: Microglial-produced nitric oxide and reactive nitrogen oxides mediate neuronal cell death. Brain Res 1992, 587: 250-256

42. Galea E, Feinstein DL, Reis DJ: Induction of calcium-independent nitric oxide synthase activity in primary rat glial cultures. Proc Natl Acad Sci USA 1992, 89: 10945-10949

43. Simmons ML, Murphy S: Induction of nitric oxide synthase in glial cells. J Neurochem 1992, 59: 897-905

44. Murphy S, Minor RL Jr, Welk G, Harrison DG: Evidence for an astrocyte-derived vasorelaxing factor with properties similar to nitric oxide. J Neurochem 1990, 55: 349-351

45. Kiedrowski L, Costa E, Wroblewski JT: In vitro interaction between cerebellar astrocytes and granule cells: a putative role for nitric oxide. Neurosci Lett 1992, 135: 59-61

46. Hiki K, Hattori R, Kawai C, Yui Y: Purification of insoluble nitric oxide synthase from rat cerebellum. J Biochem 1992, 111: 556-558

47. Vincent SR, Johansson O, Hokfelt T, Skirboll L, Elde RP, Terenius L, Kimmel J, Goldstein M: NADPH-diaphorase: a selective histochemical marker for striatal neurons containing both somatostatin- and avian pancreatic polypeptide (APP)-like immunoreactivities. J Comp Neurol 1983, 217: 252-263

48. Hibbs JB Jr, Taintor RR, Vavrin Z: Macrophage cytotoxicity: role for $\mathrm{L}$-arginine deiminase and imino nitrogen oxidation to nitrite. Science 1987, 235: 473-476

49. Knowles RG, Palacios M, Palmer RM, Moncada S: Kinetic characteristics of nitric oxide synthase from rat brain. Biochem $\mathbf{J}$ 1990, 269: 207-210

50. Moorc PK, Babbedge RC, Wallace P, Gaffen ZA, Hart SL: 7Nitro indazole, an inhibitor of nitric oxide synthase, exhibits anti-nociceptive activity in the mouse without increasing blood pressure. Br J Pharmacol 1993, 108: 296-297

51. Mayer B: Molecular characteristics and enzymology of nitric oxide synthase and soluble guanylyl cyclase in the CNS. Seminars Ncurosci 1993, 5: 197-205

52. Bogle RG, Moncada S, Pearson JD, Mann GE: Identification of inhibitors of nitric oxide synthase that do not interact with the endothelial cell L-arginine transporter. Br J Pharmacol 1992. 105: $768-770$

53. Buxton IL, Cheek DJ, Eckman D, Westfall DP. Sanders KM, Keef KD: $\mathrm{N}^{6}{ }^{3}$-nitro-L-arginine methyl ester and other alkyl esters of arginine are muscarinic receptor antagonists. Circ Res 1993, 72: $387-395$

54. Rogers NE, Ignarro LJ: Constitutive nitric oxide synthase from ccrebellum is reversibly inhibited by nitric oxide formed from Largininc. Biochem Biophys Res Commun 1992, 189: 242-249

55. Park SK, Grzybicki D, Lin HL, Murphy S: Modulation of inducible nitric oxide synthase expression in astroglial cells. Neuropharmacology 1994, 33: 1419-1423

56. Stuchr DJ, Faschun OA, Kwon NS, Gross SS, Gonzalez JA. Levi R, Nathan CF: Inhibition of macrophage and endothelial cell nitric oxide synthase by diphenyleneiodonium and its analogs. FASEB J 1991, 5: 98-103

57. Wolff DJ, Datto GA, Samatovicz RA: The dual mode of inhibition of calmodulin-dependent nitric oxide synthase by antifungal imidazole agents. J Biol Chem 1993, 268: 9430-9436

58. Nathan C: Nitric oxide as a secretory product of mammalian cells. FASEB J 1992, 6: 3051-3064

59. Jun CD, Hoon Ryu, Um JY, Kim TY, Kim JM, Kang SS, Kim HM, Chung HT: Involvement of protein kinase $C$ in the inhibition of nitric oxide production from murine microglial cells by glucocorticoid. Biochem Biophys Res Commun 1994, 199: 633-638

60. Katsuki S, Arnold WP, Murad F: Effects of sodium nitroprusside, nitroglycerin, and sodium azide on levels of cyclic nucleotides and mechanical activity of various tissues. J Cyclic Nucleotide Res 1977, 3: 239-247

61. Palmer RM, Ferrige AG, Moncada S: Nitric oxide release accounts for the biological activity of endothelium-derived relaxing factor. Nature 1987, 327:524-526

62. Ignarro LJ, Buga GM, Wood KS, Byrns RE, Chaudhuri G: Endothelium-derived relaxing factor produced and released from artery and vein is nitric oxide. Proc Natl Acad Sci USA 1987, 84: 9265-9269

63. Myers PR, Minor RL Jr, Guerra R Jr, Bates JN, Harrison DG: Vaso-relaxant properties of the endothelium-derived relaxing factor more closely resemble S-nitrosocysteine than nitric oxide. Nature 1990, 345: 161-163

64. Lipton SA, Choi YB, Pan ZH, Lei SZ, Chen HS, Sucher NJ, Loscalzo J, Singel DJ, Stamler JS: A redox-based mechanism for the neuroprotective and neurodestructive effects of nitric oxide and related nitroso-compounds. Nature 1993, 364: 626632

65. Garthwaite J, Charles SL, Chess-Williams R: Endotheliumderived relaxing factor release on activation of NMDA receptors suggests role as intercellular messenger in the brain. Nature 1988, 336: $385-388$

66. Garthwaite J, Garthwaite G, Palmer RM, Moncada S: NMDA receptor activation induces nitric oxide synthesis from arginine in rat brain slices. Eur J Pharmacol 1989, 172: 413-416

67. Garthwaite J, Southam E, Anderton M: A kainate receptor linked to nitric oxide synthesis from arginine. $J$ Neurochem 1989, 53: 1952-1954

68. Southam E, East SJ, Garthwaite J: Excitatory amino acid receptors coupled to the nitric oxide/cyclic GMP pathway in rat cerebellum during development. J Neurochem 1991, 56: 2072-2081

69. Garthwaite J: Excitatory amino acid receptors and guanosine $3^{\prime}, 5^{\prime}$-cyclic monophosphate in incubated slices of immature and adult rat cerebellum. Neuroscience 1982, 7: 2491-2497

70. Bredt DS, Snyder SH: Nitric oxide mediates glutamate-linked enlancement of cGMP levels in the cerebellum. Proc Natl Acad Sci USA 1989, 86: 9030-9033

71. Knowles RG, Palacios M, Palmer RM, Moncada S: Formation of nitric oxide from L-arginine in the central nervous system: a transduction mechanism for stimulation of the soluble guanylate cyclase. Proc Natl Acad Sci USA 1989, 86: 5159-5162

72. Marin P, Quignard JF, Lafon-Cazal M, Bockaert J: Non-classical glutamate receptors, blocked by both NMDA and non-NMDA antagonists, stimulate nitric oxide production in neurons. Neuropharmacology 1993, 32: 29-36

73. Kiedrowski L, Costa E, Wroblewski JT: Glutamate receptor agaonists stimulate nitric oxide synthase in primary cultures of cerebellar granule cells. J Neurochem 1992, 58: 335-341

74. Wood PL, Emmett MR, Rao TS, Cler J, Mick S, Iyengar S: Inhibition of nitric oxide synthase blocks $\mathrm{N}$-methyl-D-aspartate-, quisqualate-, kainate-, harmaline-, and pentylenetetrazole- 
dependent increases in cerebellar cyclic GMP in vivo. J Neurochem 1990, 55: 346-348

75. Murphy S, Minor RL, Welk G, Harrison DG: Central nervous system astroglial cells release nitrogen oxide(s) with vasorelaxant properties. J Cardiovasc Pharmacol 1991, 17 (Suppl 3): S265S268

76. Gally JA, Montague PR, Reeke GN Jr, Edelman GM: The NO hypothesis: possible effects of a short-lived, rapidly diffusible signal in the development and function of the nervous system. Proc Natl Acad Sci USA 1990, 87: 3547-3551

77. Edelman GM, Gally JA: Nitric oxide: linking space and time in the brain. Proc Natl Acad Sci USA 1992, 89: 11651-11652

78. Garg UC, Hassid A: Nitric oxide decreases cytosolic free calcium in Balb/c 3T3 fibroblasts by a cyclic GMP-independent mechanism. J Biol Chem 1991, 266: 9-12

79. Northington FJ, Matherne GP, Berne RM: Competitive inhibition of nitric oxide synthase prevents the cortical hyperemia associated with peripheral nerve stimulation. Proc Natl Acad Sci USA 1992, 89: 6649-6652

80. Holscher C, Rose SP: An inhibitor of nitric oxide synthesis prevents memory formation in the chick. Neurosci Lett 1992, 145: $165-167$

81. Snyder SH: Nitric oxide: first in a new class of neurotransmitters? Science 1992, 257: 494-496

82. Shibuki K, Okada D: Endogenous nitric oxide release required for long-term synaptic depression in the cerebellum. Nature 1991, 349: 326-328

83. O'Dell TJ, Hawkings RD, Kandel ER, Arancio O: Tests of the roles of two diffusible substances in long-term potentiation: evidence for nitric oxide as a possible early retrograde messenger. Proc Natl Acad Sci USA 1991, 88: 11285-11289

84. Schuman EM, Madison DV: A requirement for the intercellular messenger nitric oxide in long term potentiation. Science 1991, 254: $1503-1506$

85. Haley JE, Wilcox GL, Chapman PF: The role of nitric oxide in hippocampal long-term potentiation. Neuron 1992, 8: 211-216

86. Izumi Y, Clifford DB, Zorumski CF: Inhibition of long-term potentiation by NMDA-mediated nitric oxide rclease. Science 1992, 257: 1273-1276

87. Meffert MK, Premack BA, Schulman H: Nitric oxide stimulates $\mathrm{Ca}^{2+}$-independent synaptic vesicle release. Neuron 1994, 12: $1235-1244$

88. Chapman PF, Atkins CM, Allen MT, Haley JE, Steinmetz JE: Inhibition of nitric oxide synthesis impairs two different forms of learning. Neuroreport 1992, 3: 567-570

89. Bohme GA, Bon C, Lemaire M, Reibaud M, Piot O, Stutzmann JM, Doble A, Blanchard JC: Altered synaptic plasticity and memory formation in nitric oxide synthase inhibitor-treated rats. Proc Natl Acad Sci USA 1993, 90: 9191-9194

90. Oh S, Cai Z, Rochold RW, McCaslin PP: Similar effects of $\mathbf{N}^{{ }^{\omega}}$ monomethyl-L-arginine (L-NMMA) and sodium nitroprusside (SNP) on NMDA-induced glutamate release and elevation of intracellular calcium levels, but opposite effects on the NMDAinduced elevation of cylic GMP in neuronal culture. Abst Soc Neurosci 1992, 18: 256

91. Montague PR, Gancayco CD, Winn MJ, Marchase RB, Friedlander MJ: Role of NO production in NMDA receptor-mediated neurotransmitter release in cerebral cortex. Science 1994, 263 : 973-977

92. Gribkoff VK, Lum-Ragan JT: Evidence for nitric oxide synthase inhibitor-sensitive and insensitive hippocampal synaptic potentiation. J Neurophysiol 1992, 68: 639-642
93. Ito $\mathrm{M}, \mathrm{Karachot} \mathrm{L}$ : Messengers mediating long-term desensitization in cerebellar Purkinje cells. Neuroreport 1990, 1: 129-132

94. Hope BT, Michael GJ, Knigge KM, Vincent SR: Neuronal NADPH diaphorase is a nitric oxide synthase. Proc Natl Acad Sci USA 1991, 88: 2811-2814

95. Lowenstein CJ, Snyder SH: Nitric oxide, a novel biologic messenger. Cell 1992, 70: 705-707

96. Ferrante RJ, Kowall NW, Beal MF, Richardson EP Jr, Bird ED, Martin JB: Selective sparing of a class of striatal neurons in Huntington's disease. Science 1985, 230: 561-563

97. Uemura Y, Kowall NW, Beal MF: Selective sparing of NADPHdiaphorase-somatostatin-neuropeptide $\mathrm{Y}$ neurons in ischemic gerbil striatum. Ann Neurol 1990, 27: 620-625

98. Beal MF, Kowall NW, Ellison DW, Mazurek MF, Swartz KJ, Martin JB: Replication of the neurochemical characteristics of Huntington's disease by quinolinic acid. Nature 1986, 321: 168171

99. Koh JY, Peters S, Choi DW: Neurons containing NADPHdiaphorase are selectively resistant to quinolinate toxicity. Science 1986, 234: 73-76

100. Choi DW: Glutamate neurotoxicity and diseases of the nervous system. Neuron 1988, 1: 623-634

101. Regan RF, Renn KE, Panter SS: NMDA neurotoxicity in murine cortical cell cultures is not attenuated by hemoglobin or inhibition of nitric oxide synthesis. Neurosci Lett 1993, 153: 5356

102. Pauwels PJ, Leysen JE: Blockade of nitric oxide formation does not prevent glutamate-induced neurotoxicity in neuronal cultures from rat hippocampus. Neurosci Lett 1992, 143: 27-30

103. Nowicki JP, Duval D, Poignet H, Scatton B: Nitric oxide mediates neuronal death after focal cerebral ischemia in the mouse. Eur J Pharmacol 1991, 204: 339-340

104. Beckman JS, Crow JP: Pathological implications of nitric oxide, superoxide and peroxynitrite formation. Biochem Soc Trans 1993, 21: 330-334

105. Lei SZ, Pan ZH, Aggarwal SK, Chen HS, Hartman J, Sucher NJ, Lipton SA: Effect of nitric oxide production on the redox modulatory site of the NMDA receptor-channel complex. Neuron 1992, 8: 1087-1099

106. Rosen DR, Siddique T, Patterson D, Figlewicz DA, Sapp P, Hentati A, Donaldson D, Goto J, O'Regan JP, Deng HX: Mutations in $\mathrm{Cu} / \mathrm{Zn}$ superoxide dismutase gene are associated with familial amyotrophic lateral sclerosis. Nature 1993, 362: $59-62$

107. Lafon-Cazal M, Pietri S, Culcasi M, Bockacrt J: NMDA-dependent superoxide production and neurotoxicity. Nature 1993. 364: $535-537$

108. Dykens JA, Stern A, Trenkner E: Mechanism of kainate toxicity to cercbellar neurons in vitro is analogous to reperfusion tissue injury. J Neurochem 1987, 49: 1222-1228

109. Lafon-Cazal M. Culcasi M, Gaven F, Pietri S, Bockaert J: Nitric oxide, superoxide and peroxynitrite: putative mediators of NMDA-induced cell death in cerebellar granule cells. Neuropharmacology 1993, 32: 1259-1266

110. Dawson VL, Dawson TM, Uhl GR, Snyder SH: Human immunodeficiency virus type 1 coat protein neurotoxicity mediated by nitric oxide in primary cortical cultures. Proc Natl Acad Sci USA 1993, 90: 3256-3259

111. Lolley RN, Farber DB, Rayborn ME, Hollyfield JG: Cyclic GMP accumulation causes degeneration of photorcceptor cells: stimulation of an inherited diseasc. Science 1977, 196: 664-666 